\section{How news media responded to India's relationship with Britain}

\author{
DR PHILIP CASS is PJR reviews editor \\ and senior lecturer in the Department \\ of Communication Studies at Unitec, \\ Auckland.
}

Communications, Media and the Imperial Experience, by Chandrika Kaul. Basingstoke: Palgrave Macmillan, 2014, 278 pp. ISBN 978-0230-57258-4

CHANDRIKA Kaul's latest book begins and ends with what she regards as carefully stage-managed displays of British power designed to establish enduring images of imperial rule; in one, Indians and Britons bonded by their love of their King-Emperor and in the other, a noble, benevolent Britannia handing power to India as its civilising mission comes to a natural and peaceful end.

Kaul, from St Andrews University in Scotland, has written or edited a number of books exploring imperial media systems and in this latest volume she explores how the media reacted to various stages in India's relationship with Great Britain during the 20th century.

One writer described Britain and India in the 20th century as being like two people who had been dancing together for so long that they could not work out how to disentangle themselves without losing

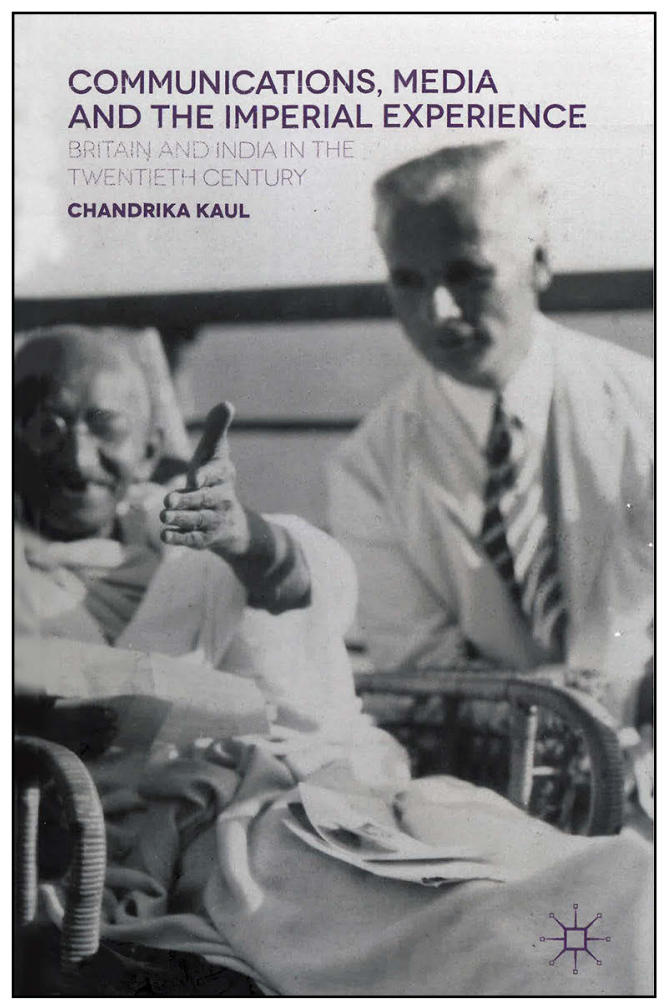

their dignity. It is this process of disentanglement that provides the background for Kaul's book.

She begins with an exploration of the Delhi Durbar in 1911, the great pageant designed to make real through the presence of George $\mathrm{V}$ the claim that the British monarch was also emperor of India. It would be, the editor of The Observer wrote:

....an event raising conscience and imagination alike to a higher power [it] will be no hollow process of grandiose pomp and glittering ostentation, but will be for the permanent good of India and the renewed strengthening of the Monarchy in the sight of all the people over whom the sceptre of Britain stretches its sway. (p. 25) 
Quite apart from its local political significance and the fact that parts of the British press were able to claim that its success demonstrated that Indians and Britons alike were bonded in loyalty to the King Emperor, it also provided audiences with some of the earliest colour film of the British empire, a ceremonial cavalry charge having been recorded in a two-tone film process. This is not, however, simply another book about Britain and India. Kaul looks at how the American journalist William L. Shirer (later to become famous as the author of The Rise and Fall of the Third Reich), J.A. Mills and other members of the American media covered the Indian story and helped to create the Ghandian myth.

Kaul traces the first inkling of the situation in India among American readers to Mark Twain's visit in 1896. American support for the Indian nationalist cause among its intellectual classes sits, in retrospect, somewhat uneasily against the American government's own imperialism of the time and its readiness to invade Latin American countries south of the Rio Grande and suborn their governments as it saw fit.

Nevertheless, by the time of Ghandi's march to the sea, political action by Indians in America and their local supporters had ensured that he garnered international coverage to such an extent that despite efforts by the British administration to make Ghandi invisible in the local media, the Postmaster-General of Bombay had to admit that there was nothing he could legally do to hinder the sending of telegrams by the journalists covering the march.

As the century progressed, a halfhearted attempt was made to establish a radio network, modelled along Reithian lines. Kaul devotes a quarter of the book to examining Indian radio's first, faltering steps, and paints a sympathetic picture of Lionel Fielden, the British official sent out to breathe life into the system, only to face obstruction and indifference at almost every turn. One Indian leader declared: 'The villager doesn't want your beastly wireless: he wants food and soap.' (p. 162) Elsewhere he rubbed up badly against the government of India and although some of his successors, at least, recognised that his achievements under the circumstances had been monumental, he was effectively fired in 1940 after five years' service. Fielden lamented:

I hated Indian inefficiency...inferiority complex...noise and...dirt, just as much as I hated British cruelty...patronage...complacency and... bad taste. And so, loving nobody, I found myself, so to speak, in the middle of an Asiatic rugby scrum in which I kicked everybody and everybody kicked me. (p. 164)

One of the curiosities of history that Kaul notes in this chapter is that the BBC's founder, Lord Reith, longed to be Viceroy of India, and was bitterly disappointed when the position went to Lord Mountbatten. It is Mountbatten who dominates the final chapter on independence.

Mountbatten's war-time career had not been unblemished. He lost his ship, the HMS Kelly, and masterminded the disastrous Dieppe landing, a catastrophe for which Canadian veterans never forgave him. These were matters for which any ordinary officer would have been court-martialled, but being a quasi-royal, he was instead packed off 
to India to serve as overlord of the allied campaign against the Japanese, in which capacity he performed well.

Having been given the Vice Regency, his task was to extract Britain from India, keep the press on side and make sure that he was always in the limelight. This he did, with the assistance of a devoted team, his wife Edwina (who dallied with Nehru) and his daughter Pamela.

Unable to persuade the Muslim leader Jinnah to agree to a united India, Mountbatten subdivided the subcontinent into India, West and East Pakistan and set a date for independence. He was indefatigable in organising and managing the media, either by himself or through his subordinates, charmed the BBC into submission, organised newsreel coverage and generally set the tone for the coverage.

As Kaul demonstrates, the tone-in the British press at least—was generally one of satisfaction that Britain had done its job, educated the Indians to the point where they could take over the reins and was able to walk away with dignity and a sense of quiet satisfaction.

\section{Mountbatten wrote:}

We started off with the utmost pomp of which we were capable and I was determined that we'd go down with colours flying very high. (p. 217)

And then he admitted:

It was a close race, we just pulled it off. (p. 217)

Since India gained independence in 1947, British, Australian and New Zealand flags have been lowered across the Pacific. Communication, Media and the Imperial Experience will hopefully inspire an equally intimate examination of the role of the media in their stories.

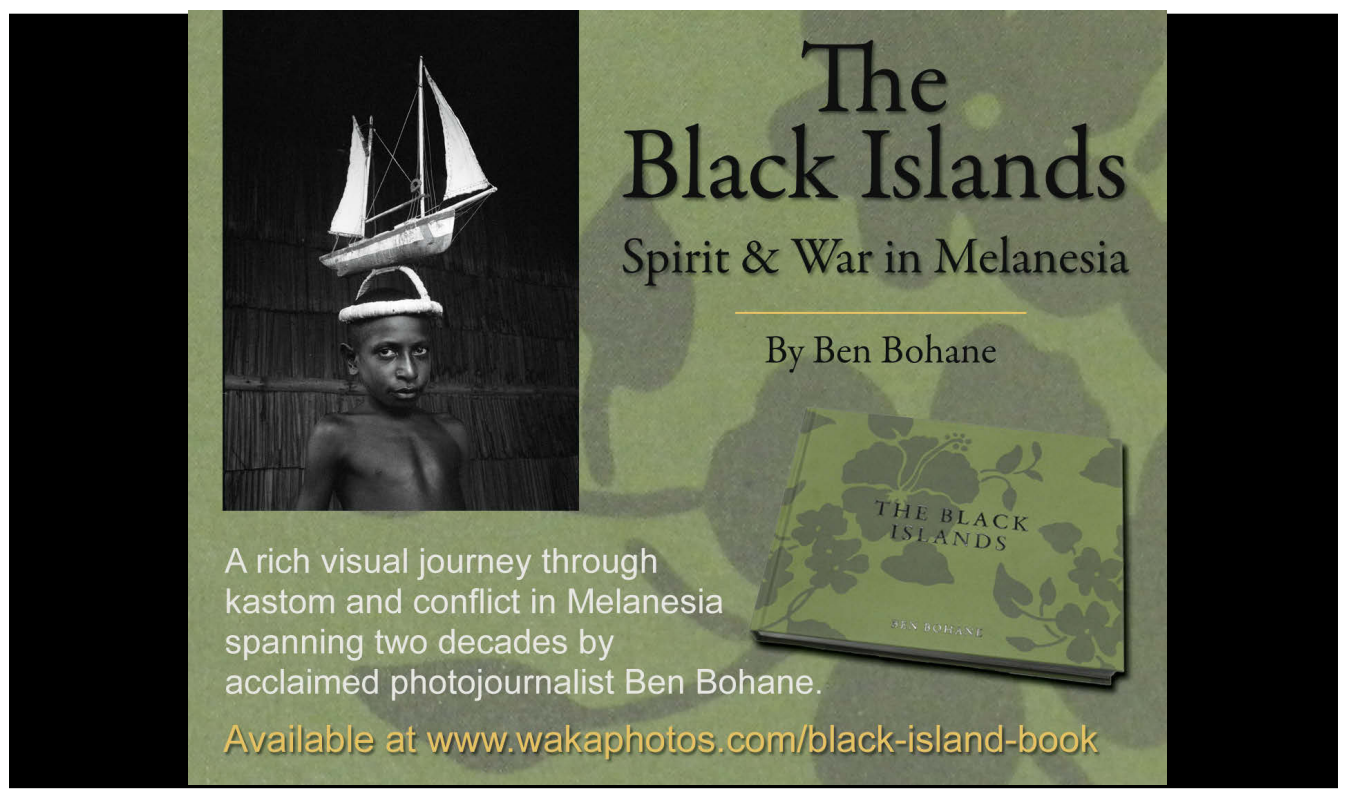

PACIFIC JOURNALISM REVIEW 21 (1) 2015207 